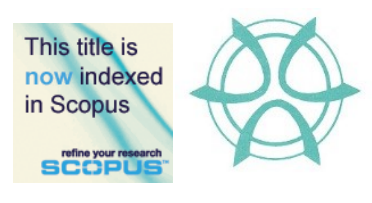

PLANNING MALAYSIA:

Journal of the Malaysian Institute of Planners

VOLUME 18 ISSUE 2 (2020), Page 181 - 192

\title{
THE ATTRIBUTES OF 'PAPAN MELEH' - ROOF EAVES DECORATION IN BAITUL RAHMAH (KUALA KANGSAR, PERAK, MALAYSIA) WITH THE HISTORIC BUILDING INFORMATION MODELLING (HBIM) APPLICATION
}

\author{
Abu Dzar Samsudin ${ }^{1}$, Norzalifa Zainal Abidin ${ }^{2}$, Alias Abdullah ${ }^{3} \&$ \\ Maisarah $\mathrm{Ali}^{4}$ \\ 1,2,3 Kulliyyah of Architecture and Environmental Design \\ UNIVERSITI ISLAM ANTARABANGSA MALAYSIA \\ ${ }^{4}$ Kulliyyah of Engineering \\ UNIVERSITI ISLAM ANTARABANGSA MALAYSIA
}

\begin{abstract}
Malay building decoration components had been one of the essential elements in Traditional Malay Architecture. This study aims to look in-depth into the process of inputting the attributes data of "Papan Meleh" or roof eaves decoration in Baitul Rahmah building located in Kuala Kangsar using the HBIM application. The method of study for this paper involves three processes, which are the data collection, data process and data fusion. The findings in this study reveal that the data collection from Heritage study report is insufficient in describing the attributes of the roof eaves decoration. The data collection process involves the collection of primary data from the literature review, and secondary data from the heritage report. The secondary data have its limitation in describing the attributes of "Papan Meleh". Thus, the data process phase is done to correlate the primary and secondary data in finding its generic attributes and remodelling the 2Dimensional (2D) into 3-Dimensional (3D) model using the HBIM software. The attributes are divided into tangible and intangible data of "Papan Meleh". After both 3D models of Papan Meleh and its generic attributes are done, both data are fused again through the HBIM software and a complete HBIM model is created.
\end{abstract}

Keywords: Papan Meleh or Roof eaves decoration, Baitul Rahmah, Malay traditional building, Historic Building Information Modelling (HBIM)

\footnotetext{
${ }^{1}$ Postgraduate Student at International Islamic University Malaysia. Email: abudzar.phd@gmail.com
} 
Abu Dzar Samsudin, Norzalifa Zainal Abidin, Alias Abdullah \& Maisarah Ali

The Attributes of 'Papan Meleh' - Roof Eaves Decoration in Baitul Rahmah (Kuala Kangsar, Perak, Malaysia) With Historic Building Information Modelling (HBIM) Application

\section{INTRODUCTION}

The use of Building Information Modelling (BIM) for cultural building heritage is known as Heritage Building Information Modelling (HBIM), where this new method of incorporating BIM and heritage studies is now a method to manage and document heritage building. The process covers the creation of parametric modelling, built by considering historical data and layered-in plug-in libraries that represent building components, which include both geometric and nongeometric attributes and relationship (Volk et al., 2014). This research aims to look into the processes involved in documenting heritage buildings, focusing on Papan Meleh or roof eaves decorative component in Baitul Rahmah using the HBIM application. To ease the research, the term Papan Meleh is defined as the Roof Eaves Decoration Component (REDC). The building and its specific component were chosen because the building itself was built by one of the royals of Perak, Raja Harun Ar Rashid. The components of the roof eaves are chosen as the main subject matter due to its unique design that can be seen in almost any Traditional Malay Buildings in different variations of design. By looking into the process of documenting the roof eaves decoration components, a generic framework of the process can be outlined as a reference for the other researchers and designers in producing possible design compositions and application to any future or existing buildings.

\section{LITERATURE REVIEW}

The literature review is divided into the review of the Malay roof eaves decoration, attributes of MTBD, HBIM and Heritage studies, HBIM modelling process, and heritage report on Baitul Rahmah. Firstly, an overview of the-roof eaves decoration was done on the variety of typologies of MTBD. Secondly, we carried out the overview of the attributes of MTBD as a whole. Lastly, the literature on the HBIM is also done to discuss its usage in the heritage study and the processes involved. Baitul Rahmah is the chosen case study for this paper.

\section{Papan Meleh or Malay roof eaves decoration}

The roof eaves decoration has many names, yet there is a slight difference between each of these different names. In Rashid et al., (2018), the roof eaves decoration component (REDC) is divided into three (3) types, which are Papan Meleh, Papan Layang and Kepala Cicak. This research is only focusing on the Papan Meleh component. Papan Meleh is the horizontal decorative timber roof eaves covering the timber rafters (Kayu kasau). Other names of Papan Meleh are Ande-ande, Papan Pator, Papan Cucuran Atap, Papan Kaki Atap, Kening, Papan Tumpu Kasau, Papan Cantik and Papan Pator. The difference in the term being used is due to the usage in different areas. For example, in Penang, the word Kening (eyebrow) is exclusively used, while other areas use other terms. 
Figure 1 below shows an overview of typology for REDC. The blue annotation is the focus of this study.

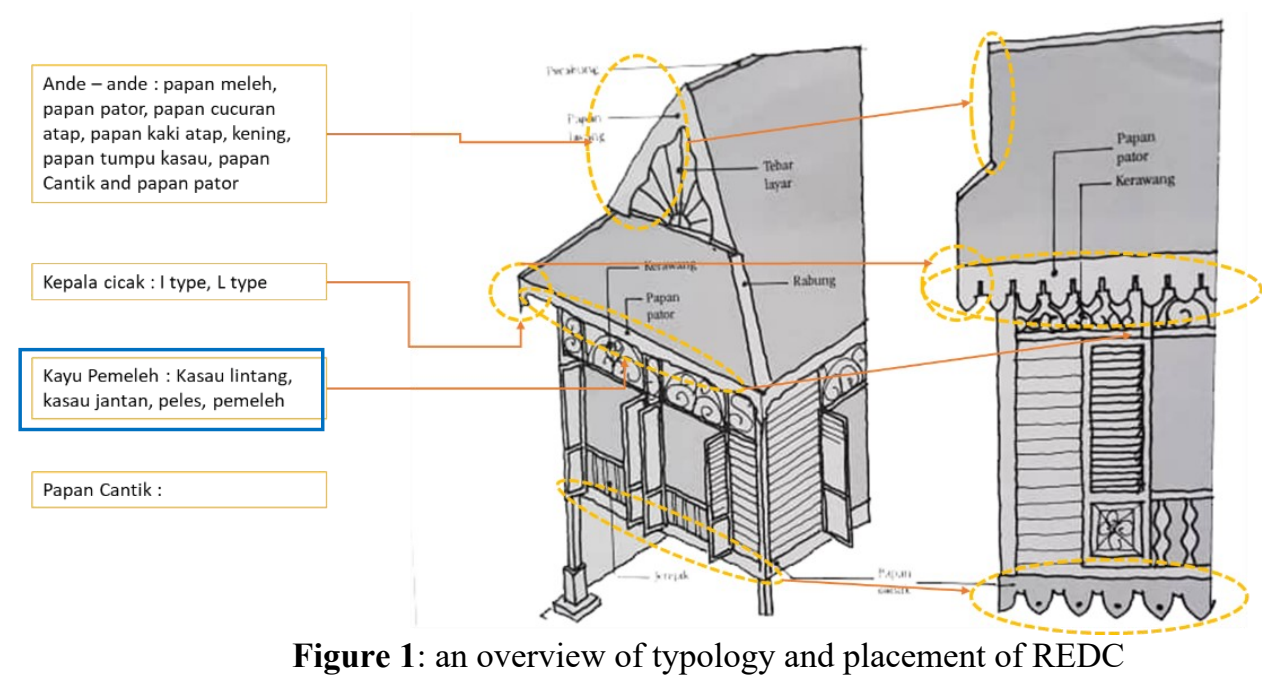

Figure 1: an overview of typology and placement of REDC Source: (Hanafi, 2000)

\section{The Attributes of Malay Traditional Building Decoration (MTBD)}

To investigate the attributes of REDC, one must look into the general attributes for MTBD component, which are divided into two (2); tangible and intangible. Tangible data is the data that can be physically perceived, and intangible data is symbolically perceived. Both attributes are important in describing any component of the Malay buildings. The process of documenting each attribute is an important part of the heritage report and documentations. Past literature investigates the data in the form of the art of woodcarving. Thus, by reviewing the principles of MTBD, this could lead to a holistic and better understanding of the attributes of MTBD. A few works of literature that listed the principle of MTBD are reviewed. The review includes Ali's (1989) views on the Malay concept of beauty, while Othman (2005) looked into the principle of composition in creating a wood-carving design. Noor (2004), in his research, highlighted six principles of the Malay aesthetic by describing, analysing and evaluating the craft products produced by Malay artisans (refer Figure 2). Each researcher looked into a different perspective; Ali (1989) studied on the concept of beauty, Othman (2005) reviewed in the composition and Noor (2004) focused on the Malay aesthetic. However, the similarity in these three researches is that all of them concentrated on the Malay Art of Woodcarving. Wood carving is strongly related to MTBD. There is a recurring similarity between each listed principle. In Figure 2 below, the diagram shows the relationship between each researcher's principle. The first similarities are all the listed principles which can be distinguished into 
Abu Dzar Samsudin, Norzalifa Zainal Abidin, Alias Abdullah \& Maisarah Ali

The Attributes of 'Papan Meleh' - Roof Eaves Decoration in Baitul Rahmah (Kuala Kangsar, Perak, Malaysia) With Historic

Building Information Modelling (HBIM) Application

intangible, tangible and both tangible and intangible (refer to Figure 2). The categorization of the tangible attributes can be quantitively distinguished, whilst the intangible components are the attributes that must be analysed through qualitative understanding. The second similarities look into the relationship between each listed principle. The diagram shows that the attributes from both tangible and intangible could be simplified into four categories, which are symbolism, nature, functional and composition (refer to Figure 3). These attributes can be used in different words, but for this research, this term is used to portray each attribute. For example, the word motif could be changed to "nature" or "vegetation". The different coding of colours in this diagram shows the different components of the relationship of the said attributes.

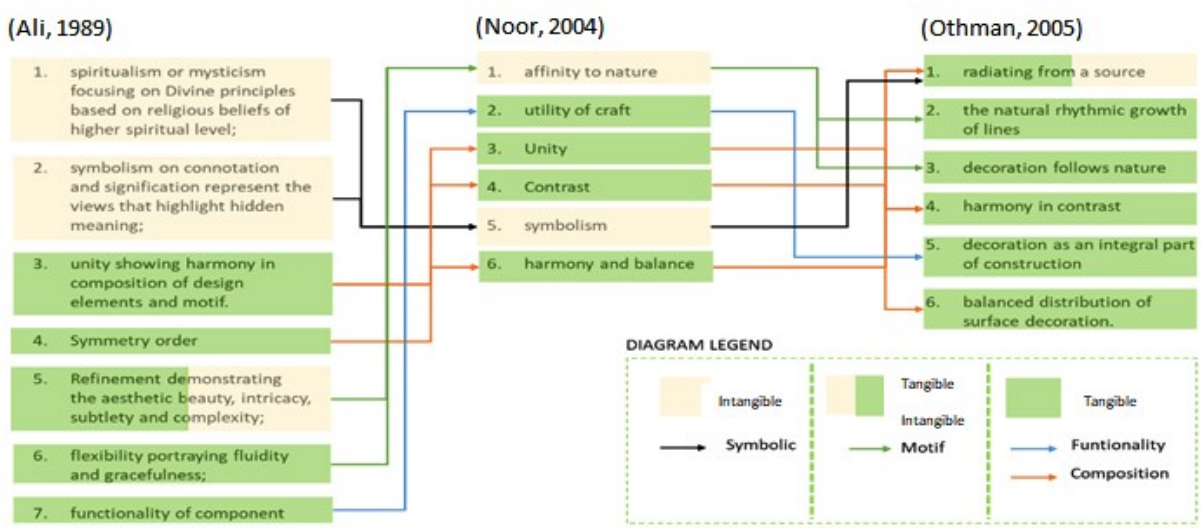

Figure 2: Malay architectural system presents the relationship of the different attributes in the decorative elements

Source: Author, 2020

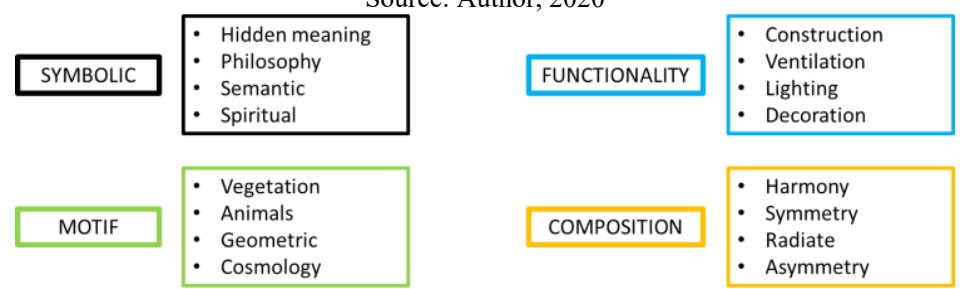

Figure 3: Attributes of MTBD

Source: Author, 2020

Detailed review on each of the four (4) attributes from Figure 3 shows a more diverse fraction of sub-attributes to be reviewed. Each main attribute (refer to diagram legend Figure 2 and Figure 3) will be further discussed in the next literature. These attributes are also supported by past research. These attributes are discussed with reference to REDC of Baitul Rahmah as a case study. 
PLANNING MALAYSIA

Journal of the Malaysia Institute of Planners (2020)

\section{Heritage Building Information Modelling (HBIM), Heritage Studies and HBIM Modelling Process}

The use of BIM for heritage studies is commonly known as the Historic Building Information Modelling (HBIM). The modelling process of HBIM from a building case study indicates the object of HBIM that comprises all building information, including tangible and intangible data. The process involves a reverseengineering solution, whereby the finished as-built drawings of the heritage buildings are extracted from the survey (Cheng \& Jin, 2006). According to Megahed (2015), the process of HBIM can be categorized into three (3) steps. The process of HBIM begins with a survey of historic buildings in order to capture data using both high-definition surveying and traditional methods. The next step involves processing the data into the construction and design of a parametric library of objects. Such models are then properly merged together, exploiting the editing capabilities to achieve a unique virtual representation of the historic building. The final step involves the fusion of data, where corresponding datasets using the BIM system define the historical object as a parametric object (Megahed, 2015). The tangible and intangible data include physical dimension, scale proportion, etc., while intangible data includes the historical facts, name of objects, symbolic meaning, etc. The tangible data helps in creating the physical 3-dimensional model whilst the intangible data provides the necessary information about the specific objects which are being modelled. The finalised HBIM models are in the form of completed engineering drawings which are comprehensive and suitable for historic conservation and management; the orthographic projections, 3-Dimensional documentation, sections, details, and schedules (Murphy, 2012).The researchers applied the same process to Baitul Rahmah as a building case study and its main subject are the REDC (Papan Meleh) of the buildings. This matter will be further discussed in the research methodology.

\section{The Case Study: Baitul Rahmah, Kuala Kangsar, Perak, Malaysia}

Baitul Rahmah is an aristocratic house, designed and built by Raja Harun AlRashid with the help of a skilled craftsman known as Tukang Sofian (Kassim et al., 2019) The house is a part of his legacy in Bukit Chandan where the building resides. Raja Harun was known to be very talented and had an eye for architecture; he was skilled with his hand, especially in the art of Malay woodcarving. Baitul Rahmah was said to be built in 1911; this is based on the handmade plaque which stated the year of 1911. The house design had an exciting fusion between the Traditional Malay architecture with British colonial style on some component areas. This study focuses on the use of REDC on Baitul Rahmah to be studied and remodelled into HBIM object as a means to record its physical looks and historical data that consist of intangible and tangible attributes. 
Abu Dzar Samsudin, Norzalifa Zainal Abidin, Alias Abdullah \& Maisarah Ali

The Attributes of 'Papan Meleh' - Roof Eaves Decoration in Baitul Rahmah (Kuala Kangsar, Perak, Malaysia) With Historic

Building Information Modelling (HBIM) Application

\section{RESEARCH METHODOLOGY}

There are three (3) processes for this case study, Baitul Rahmah. The first process is the extraction of REDC from the KAED Heritage report on the Baitul Rahmah building. The second process involves modelling the decoration component from the 2-dimensional drawing into 3-dimensional modelling, based on the physical dimensions stated in the report. The extraction of the intangible data is also listed for the decoration components. The final process is fusing the 3-dimensional modelling with more intangible data of which show the attributes of each decoration component.

\section{FINDINGS}

The findings will be discussed in three (3) sequential processes: from data collection (Process 1), data process (Process 2) and data fusion (Process 3).

\section{Process 1: Data Collection}

The data collection process in this research is divided into two tasks, which focuses on the REDC of Baitul Rahmah. The first process is to collect the related data from the Heritage report of Baitul Rahmah (Heritage Lab KAED IIUM). The second process is by reviewing the current literature from books and journals. The literature is focused on the intangible and tangible data of MTBD. Both data from the heritage report and literature review are combined and correlated with the finalization of a semantic attribute to be inputted into the HBIM Data. Based on the previous literature, four main attributes are established as the Main attributes for MTBD. Table 1 shows the three (3) sides of tangible, intangible and both intangible tangible (In-Tangible) data that are taken from different literature reviews. This data is correlated with the heritage report data. The correlation process involves cross-referencing the incomplete data from the heritage report with literature review data.

Table 1: Semantic attributes from literature

\begin{tabular}{llll}
\hline Intangible & $\begin{array}{l}\text { Intangible } \\
\text { Tangible }\end{array}$ & Tangible & \\
\hline $\begin{array}{l}\text { SYMBOLISM } \\
\text { (Muhamed, 1956) }\end{array}$ & $\begin{array}{l}\text { MOTIF } \\
\text { (Shaffee et al, 2013) }\end{array}$ & $\begin{array}{l}\text { COMPOSITION } \\
\text { (Said, 2013) }\end{array}$ & $\begin{array}{l}\text { FUNCTIONALITY } \\
\text { (Denan et al., 2015) }\end{array}$ \\
\hline
\end{tabular}

Source: Author, 2020

The collection of data from the heritage report involves the collection of the textual and pictorial data from the heritage report in the Heritage Lab KAED IIUM on Baitul Rahmah. The data would include historical, pictorial, measured 
drawing and textual information. The Table 2 below presents the data taken from the report.

Table 2: Heritage report

\begin{tabular}{|c|c|c|c|}
\hline Placement & Component & & \\
\hline 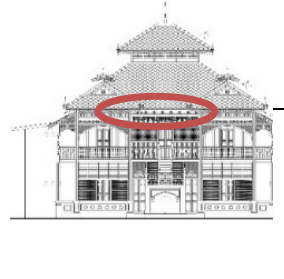 & S. & $\begin{array}{l}\text { Name: Fascia board } \\
\text {-No Malay name was } \\
\text { given } \\
\text { Material: Timber } \\
\text { Influence: } \\
\text { Traditional Malay } \\
\text { Architecture }\end{array}$ & $\begin{array}{l}\text { Details: Tebuk } \\
\text { tembus (direct } \\
\text { piercing) technique } \\
\text { Description: } \\
\text { Carved with floral } \\
\text { motif and figure of } \\
\text { a hanging bat }\end{array}$ \\
\hline
\end{tabular}

In Table 2, some component names are incomplete in terms of the Malay and translated English names. The addition of "material", "details", "influence" and "description" attributes provide useful information for the tangible attributes. These attributes could be correlated with the data from the literature to enhance further attributes of the components which consists of tangible and intangible data. Step 2 is the Data Process, which involves the construction of components from the measured drawing in the Baitul Rahmah heritage report using the REVIT software, as well as the correlation of data between the information from a literature review with the heritage report data.

\section{Process 2: 3D Modelling from REVIT}

The measured drawing of the roof eaves decoration is directly taken from the AutoCAD software. From the 2D AutoCAD drawing, a 3D model is produced by exporting the drawing into the Revit software (BIM software). The process of the $3 \mathrm{D}$ modelling from the $2 \mathrm{D}$ measurement is straight forward; no problem is detected from this process. This can be seen in Figure 4 below.

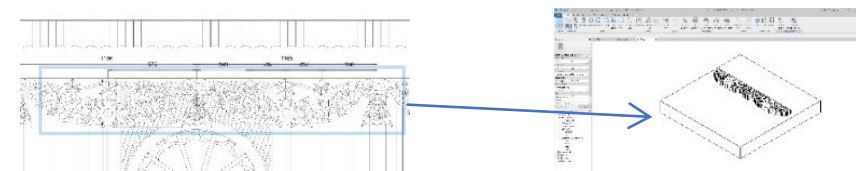

Figure 4: Detail measurement of 2D AutoCAD drawing (left), 3D modelled from 2D AutoCAD drawing (right) Source: Heritage Lab KAED (left), Author (right)

Process 2: Correlation of Data from Literature and Heritage Report

Both data are combined into one complete data. The four main attributes that are being used as a portrayal of semantic for each component is compared with the data from the heritage report. Table 3 below shows the complete data merge from 
Abu Dzar Samsudin, Norzalifa Zainal Abidin, Alias Abdullah \& Maisarah Ali

The Attributes of 'Papan Meleh' - Roof Eaves Decoration in Baitul Rahmah (Kuala Kangsar, Perak, Malaysia) With Historic

Building Information Modelling (HBIM) Application

the literature and heritage report. The heritage report is the secondary data for this research, while the literature is the primary data. Table 1 and 2 shows the attributes from the heritage report and literature review. The attributes on the material, description, details and influence portray a tangible description of the component, which is lacking from the attributes in the literature reviews except for the motif description. These attributes from the heritage report can be grouped under "descriptions" attributes, as all the attributes focus on describing the physical qualities of the component (refer to Table 3). The original description from the heritage report mentioned that the motif that was used can be merged with the motif attributes from the literature. The absence of some data such as the Malay name for the component can be inputted by looking into the available literature. For example, in the table above, fascia board is found in the heritage report only as "fascia board" which is in English terminologies. However, with reference to the other literature from the literature review, fascia board are called "Papan Meleh" in Malay, based on the work from (Hanafi, 2000). This would prove that both data are vital in giving a holistic view of the semantic attributes for each component. The table below is the finalized attributes that will be used for each component.

Table 3: finalize semantic attributes from correlate data

\begin{tabular}{ll}
\hline Measured drawing & Attributes \\
\hline \multirow{3}{*}{ Site image } & Name: \\
& Papan Meleh (Hanafi, 2000) \\
\cline { 2 - 2 } & Symbolism: - \\
\cline { 2 - 2 } & Motif: \\
& Floral - unidentified plants \\
& Fauna - hanging bat \\
\hline & Composition: \\
& $\begin{array}{l}\text { Symmetry composition from the hanging } \\
\text { bat motif as the center }\end{array}$ \\
\cline { 2 - 2 } & Functional: \\
& $\begin{array}{l}\text { To cover the Kasau Jantan (main rafter) } \\
\text { from being directly exposed to sunlight } \\
\text { and rain (Hanafi, 2000) }\end{array}$ \\
& Description: \\
& The component is in timber material \\
& carved using a direct piercing method \\
& and influenced by Traditional Malay \\
& architecture. \\
\hline
\end{tabular}

Source: Author, 2020 
The process from Process 2 produces two data of a complete 3D model of the decorative components, and the finalized semantic attributes. Both data are still incomplete if they are separated. Thus, comes the next process, which is to fuse both data to get a complete HBIM data.

\section{Process 3: Data Fusion}

In Process 3, data fusion is implemented. This process involves the combination of the attributes data from Process 1 and 2 with the 3D model process data from Process 2. In order to input attributes, the first step is to open the 3D model on the component that has been created. Then, we select the "Properties Area" and click on "Family Type" (refer to Figure 5).

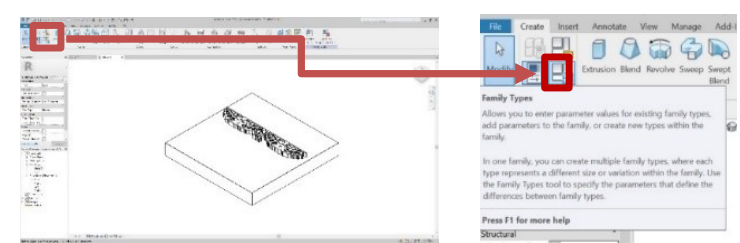

Figure 5: Properties Area to Family Type

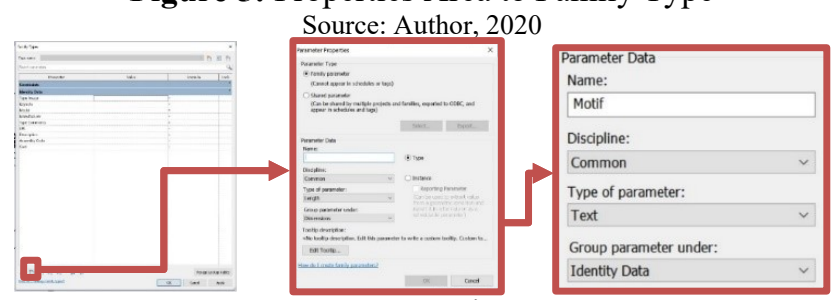

Figure 6: Parameter Properties to Parameter Data Source: Author, 2020

From the "Family Type", we click on the Parameter Properties and the semantic data of REDC is then inputted into the Parameter Data's area. A total of 4 properties data, ranging from name, discipline, type of parameter and group parameter, are linked with the finalised attributes from Process 2. Figure 6 shows an example of some attributes that fuses into the Parameter Data of the REVIT software. The attributes consist of textual and pictorial data from the site. For textual data, the type parameter used is "text" and for group parameter, it would be placed under "identity data" (refer Figure 6). Figure 7 is an example of inputting "motif" attributes into the Parameter Data of the REVIT software. The figure below presents the completed data fusion process. 
Abu Dzar Samsudin, Norzalifa Zainal Abidin, Alias Abdullah \& Maisarah Ali

The Attributes of 'Papan Meleh' - Roof Eaves Decoration in Baitul Rahmah (Kuala Kangsar, Perak, Malaysia) With Historic Building Information Modelling (HBIM) Application

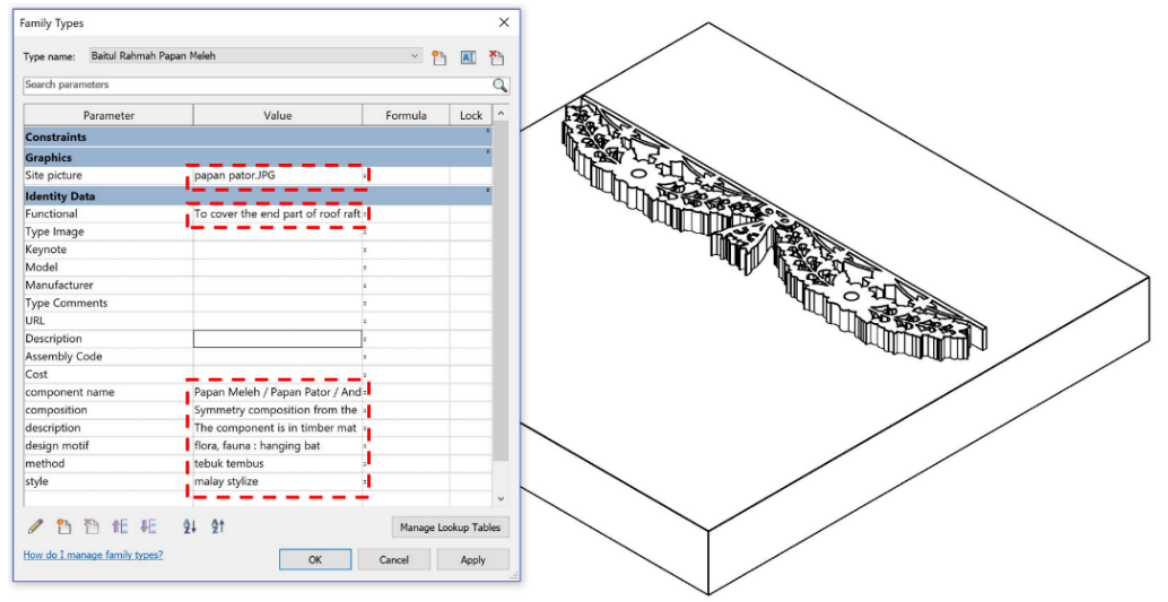

Figure 7: Inputted Parameter Data (red dotted box annotation) Source: Author, 2020

The overall process of attribute enrichment of the Papan Meleh in Baitul Rahmah is further enriched in the 3D modelling. There are some limitations to this study. The first limitation is that the creation of the semantic attributes is limited to textual and pictorial data. Despite the fact that this data is enough to portray the semantic attributes of each component, there are still other attributes that could be explored, such as linking the component of the 3D model with a specific website by utilizing the Universal Resource Locator (URL) link function. The second limitation is in the ontological system for each 3D model, and each 3D component was modelled separately without a proper link to other 3D components. For future research, one could look closely on the ontological system of Malay Architecture. The third limitation is in the completion of the information. More data are needed to complete the full semantic attributes, especially on the name that is used to define the components. For example, from the heritage report, the name of fascia board is known to be only "fascia board" without its Malay name. Only after linking the data with the past literature that we get to know that "fascia board" is called "Papan Meleh" in Malay. To simply call it Papan Meleh is not enough, as the name is a general term or name that defines the type of decorative components that reside at the edge of the roof. Additional research is needed to find a suitable method in naming every decorative component in relation to its specific design attributes in the traditional Malay buildings, knowing this can help in understanding the application of decorative component not only for its general means but also its personal design attributes. Figure 8 presents the finalized framework of HBIM creation for MTBD. 


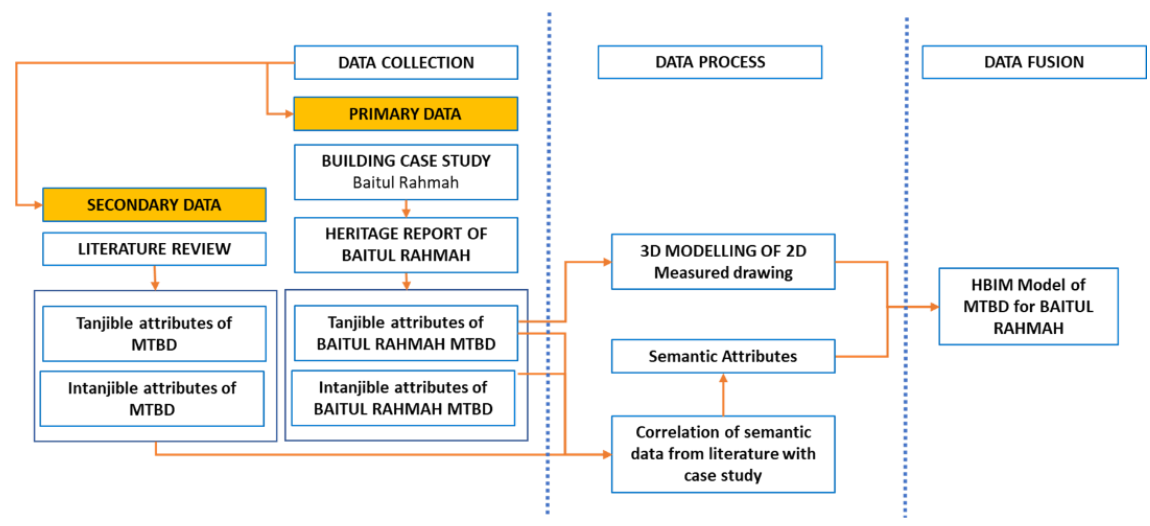

Figure 8: Proposed Framework to input attributes Data of REDC using HBIM application (REVIT)

\section{CONCLUSION}

Source: Author, 2020

The process of HBIM modelling for REDC in Baitul Rahmah is doable with a bit of limitation. The 3-step framework must be followed to get a proper HBIM model with rich information. The first step of the Data Collection is important in establishing the semantic attributes of each decorative component. This phase can be improved for future research as there can be additional attributes that could be added to this paper's semantic attributes. The second step of the Data Processing involves the process of textual data analysis and the building of a physical 3D model for each component. The finalized textual data create the primary attributes for a REDC and become the basic information that defines each decorative component in Baitul Rahmah. This data will be paired or fused with the completed 3D model of each decorative components from the same building. Fusing both data is the final process whereby it includes a specific step, as stated before. A complete HBIM data is created after the final step is done, yet there are still some limitations that are needed to be explored in the future research. This research establishes a framework that could be applied to other potential heritage building. Hopefully, this framework would be useful in the building heritage conservation industry in the field of HBIM application.

\section{ACKNOWLEDGEMENTS}

This research was supported by a grant TRGS/1/2016/UIAM/01/5/3 from the Ministry of Higher Education Malaysia (MOHE). This research is also supported by Kulliyyah of Architecture and Environmental Design (KAED) and Kulliyyah of Engineering of International Islamic University Malaysia

\section{REFERENCES}

Ali, Z. (1989). Seni dan Seniman: Esei-esei Seni Halus. Dewan Bahasa dan Pustaka. 
Abu Dzar Samsudin, Norzalifa Zainal Abidin, Alias Abdullah \& Maisarah Ali

The Attributes of 'Papan Meleh' - Roof Eaves Decoration in Baitul Rahmah (Kuala Kangsar, Perak, Malaysia) With Historic

Building Information Modelling (HBIM) Application

Cheng, X. J., \& Jin, W. (2006). Study on reverse engineering of historical architecture based on 3D laser scanner. Journal of Physics: Conference Series, 48(1), 843 849. https://doi.org/10.1088/1742-6596/48/1/160

Denan, Z., Majid, N. H. A., \& Arifin, N. (2015). Ingenious Malay Wood Carving as Daylight Filtering Devices. Procedia - Social and Behavioral Sciences, 201(October), 182-190. https://doi.org/10.1016/j.sbspro.2015.08.167

Hanafi, Z. (2000). Pola-Pola Hiasan di Dalam Bangunan Tradisional Melayu (1st ed.). Dewan Bahasa dan Pustaka.

Kassim, S. J., Majid, N. A., Shariff, H. M., \& Qarihah, T. A. (2019). The hybrid aesthetics of the malay vernacular: Reinventing classifications through the classicality of South East Asia's palatial forms. International Journal of Recent Technology and Engineering, 8(1), 340-350

Megahed, N. A. (2015). Towards A Theoretical Framework For Hbim Approach In Historic. 9(3), 130-147.

Muhamed, A. (1956). Falsafah kesenian Melayu ( Pandangan Nakula tentang konsep kesenian Melayu ). 1-10.

Murphy, M. (2012). Historic Building Information Modelling (HBIM). For Recording and Documenting Classical Architecture in Dublin 1700 to 1830. Handbook of Research on Emerging Digital Tools for Architectural Surveying, Modeling, and Representation, (April), 233-273. https://doi.org/10.4018/978-1-4666-83792.ch007

Othman, R. (2005). The language of the Langkasukan motif. Indonesia and the Malay World. https://doi.org/10.1080/13639810500281898

Rashid, S., Abdul Halim Choo, I., Ramele, R., Baharuddin, M. N., Alauddin, K. (2018). Decorative Elements of Traditional Malay Houses: Case Study of Rumah Limas Bumbung Perak (RLBP). The Journal of Social Sciences Research, (6), 105-115. https://doi.org/10.32861/jssr.spi6.105.115

Shaffee, N., \& Said, I. (2013). Types of Floral Motifs and Patterns of Malay Woodcarving in Kelantan and Terengganu. Procedia - Social and Behavioral Sciences. https://doi.org/10.1016/j.sbspro.2013.11.049

Said, I. (2013). Visual Composition of Malay Woodcarvings in Vernacular Houses of Peninsular Malaysia. Jurnal Teknologi, 37(1), 43-52. https://doi.org/10.11113/jt.v37.527

Noor, S. Z. (2004), The Malay Concept of Aesthetics with Special Focus on Crafts. In: Nazeih Taleb Maarouf (Ed.). Creativity and Crafts in the Muslim World: Islamic Crafts Series:7, Istanbul: IRCICA

Volk, R., Stengel, J., \& Schultmann, F. (2014). Building Information Modeling (BIM) for existing buildings - Literature review and future needs. Automation in Construction, 38(October 2017), 109-127. https://doi.org/10.1016/j.autcon.2013.10 